\title{
Evaluasi Kebutuhan Luasan Apron Pada Rencana Pengembangan Bandar Udara Internasional Ahmad Yani Semarang
}

\author{
Muhammad Nursalim, Ervina Ahyudanari, dan Istiar \\ Jurusan Teknik Sipil, Fakultas Teknik Sipil dan Perencanaan, Institut Teknologi Sepuluh Nopember (ITS) \\ Jl. Arief Rahman Hakim, Surabaya 60111 Indonesia \\ e-mail: ervina@ce.its.ac.id, istiar@ce.its.ac.id
}

\begin{abstract}
Abstrak - Bandar Udara Ahmad Yani akan memiliki terminal yang lebih luas di sebelah Utara runway, lahan parkir yang luas, apron seluas $61.344 \mathrm{~m} 2$ serta dua buah taxiway. Pengembangan tahap II akan menjadikan Bandar Udara Ahmad Yani memiliki apron seluas $72.522 \mathrm{~m} 2$ dan 10 buah taxiway serta 1 buah parallel taxiway. Studi ini akan mengevaluasi kebutuhan apron Bandar Udara internasional Ahmad Yani Semarang saat ini dan 20 tahun kedepan. Pada evaluasi ini akan diprediksi jumlah pergerakan pesawat pada tahun rencana yang kemudian akan dikonversi menjadi jumlah pesawat pada jam sibuk. Hasil prediksi jumlah pesawat ini akan dianalisis terhadap kebutuhan apron Bandar Udara Ahmad Yani di tahun rencana. Dengan adanya pengembangan apron diharapkan dapat memenuhi kebutuhan lalu lintas udara. Untuk perencanaan perkerasan apron menggunakan rigid pavement dengan metode FAA dengan software FAARFIELD. Dari hasil perhitungan didapatkan, kebutuhan total jumlah gerbang landas parkir untuk tahun rencana (2035) adalah 51 pesawat, yang terdiri dari 35 kelas $\mathrm{C}$ dan 16 kelas D. Selanjutnya didapatkan dimensi gerbang landas parkir pada tahun rencana (2035) adalah untuk kelas $\mathrm{C}$ dengan panjang 2096,50 m dan lebar 98,37 m sedangkan untuk kelas D dengan panjang $1547,20 \mathrm{~m}$ dan $104,78 \mathrm{~m}$. Tebal perkerasan landas parkir ini adalah $670 \mathrm{~mm}$. Dalam penulangan perkerasan landas parkir tahun rencana (2035) dibutuhkan wiremesh dengan D14-100 dan Dowel dengan diameter $50 \mathrm{~mm}$, panjang $610 \mathrm{~mm}$, dan jarak 460 mm.
\end{abstract}

Kata Kunci - Kebutuhan Apron, Kapasitas Apron, Pergerakan Pesawat Tahun Rencana, Perkerasan dengan Software FAARFIELD.

\section{PENDAHULUAN}

B ANDAR Udara Internasional Ahmad Yani Semarang merupakan salah satu bandara internasional yang di kelola oleh PT Angkasa Pura 1 (Persero), sebagai pintu gerbang dan ujung tombak lalu lintas udara yang berlokasi di bagian barat Kota Semarang. Bandar udara ini melayani penerbangan domestik dan penerbangan Internasional. Pada saat ini kapasitas Bandar Udara Internasional Ahmad Yani Semarang pada sisi udara meliputi runway yang mempunyai panjang landasan 2.680 meter dengan lebar 45 meter, sebuah taxiway yang menghubungkan antar apron dengan runway dan kapasitas apron dengan luas $29.008 \mathrm{~m} 2$ yang hanya mampu menampung 8 pesawat (6 narrow body dan 2 pesawat kecil). PT Angkasa Pura 1 melakukan pengembangan sisi udara dalam dua tahap. Tahap I yang direncanakan selesai tahun 2017 meliputi pembangunan terminal baru di sebelah Utara runway, perluasan apron seluas $61.344 \mathrm{~m} 2$ yang mampu menampung 10 pesawat dan pembangunan 2 buah taxiway. Sedangkan pada tahap II akan direncanakan pengembangan apron seluas 72.522 $\mathrm{m} 2$ dan taxiway berjumlah 10 buah dan 1 buah paralel taxiway [1]. Hal ini sejalan dengan target pemerintah yang terdapat dalam PM 69 tahun 2013 yang menyatakan bahwa fungsi Bandar Udara Internasional Ahmad Yani Semarang adalah sebagai PS (Pengumpul skala Sekunder), sedangkan pada tahun 2030 fungsi bandara menjadi PP (Pengumpul skala Primer).
Maka dapat kita simpulkan perlu dilakukan evaluasi kebutuhan apron dan mengenai kinerja penggunaan apron selama beberapa tahun mendatang agar didapat solusi yang tepat untuk mengatasi peningkatan kebutuhan pesawat. Maka judul studi ini adalah Evaluasi Kebutuhan Apron Rencana Pengembangan Bandar Udara Internasional Ahmad Yani Semarang .

\section{METODE PENELITIAN}

\section{A. Identifikasi Masalah}

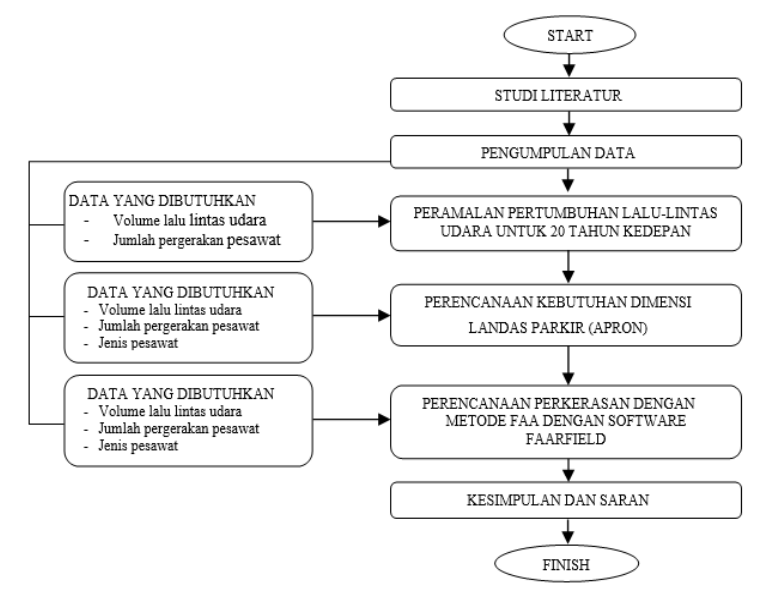

Gambar 1. Diagram Alir Metodologi

\section{HASIL DAN PEMBAHASAN}

A. Peramalan Pertumbuhan Pergerakan Pesawat

Untuk mendapatkan perhitungan kebutuhan pertumbuhan pergerakan pesawat di tahun rencana dibutuhkan data histori pergerakan pesawat. Adapun data pergerakan pesawat Bandar Udara Internasional Ahmad Yani Semarang pada tahun 20112015 yang akan digunakan ditunjukkan pada tabel berikut.

Tabel 1.

Data Pergerakan Pesawat Tahun 2011-2015 [2]

\begin{tabular}{|c|c|c|c|c|c|c|c|c|c|c|c|}
\hline \multirow{2}{*}{ No } & \multirow{2}{*}{ Bulan } & \multicolumn{2}{|c|}{2011} & \multicolumn{2}{c|}{2012} & \multicolumn{2}{c|}{2013} & \multicolumn{2}{|c|}{2014} & \multicolumn{2}{|c|}{2015} \\
\cline { 2 - 12 } & & Arr & Dep & Arr & Dep & Arr & Dep & Arr & Dep & Arr & Dep \\
\hline 1 & Januari & 842 & 843 & 1027 & 1024 & 1207 & 1205 & 1243 & 1234 & 1278 & 1301 \\
\hline 2 & Februari & 791 & 789 & 985 & 985 & 1118 & 1112 & 1088 & 1086 & 1199 & 1201 \\
\hline 3 & Maret & 1004 & 1004 & 1210 & 1210 & 1231 & 1228 & 1374 & 1379 & 1500 & 1518 \\
\hline 4 & April & 959 & 956 & 1197 & 1192 & 1200 & 1219 & 1210 & 1200 & 1563 & 1554 \\
\hline 5 & Mei & 939 & 934 & 1205 & 1215 & 1266 & 1247 & 1338 & 1368 & 1590 & 1588 \\
\hline 6 & Juni & 902 & 905 & 1203 & 1190 & 1255 & 1258 & 1452 & 1456 & 1391 & 1398 \\
\hline 7 & Juli & 1067 & 1066 & 1141 & 1136 & 1222 & 1216 & 1373 & 1353 & 1615 & 1611 \\
\hline 8 & Agustus & 890 & 883 & 1266 & 1267 & 1362 & 1377 & 1547 & 1534 & 1670 & 1670 \\
\hline 9 & Septembe & 1021 & 1021 & 1241 & 1238 & 1354 & 1350 & 1365 & 1397 & 1518 & 1539 \\
\hline 10 & Oktober & 1056 & 1051 & 1218 & 1211 & 1332 & 1318 & 1427 & 1428 & 1678 & 1680 \\
\hline 11 & Nopembe & 958 & 955 & 1229 & 1222 & 1314 & 1312 & 1415 & 1415 & 1551 & 1548 \\
\hline 12 & Desember & 1017 & 1017 & 1233 & 1233 & 1383 & 1400 & 1456 & 1463 & 1646 & 1650 \\
\hline Jumlah & 11446 & 11424 & 14155 & 14123 & 15244 & 15242 & 16288 & 16313 & 18199 & 18258 \\
\hline \multicolumn{2}{|c|}{ Total } & 22870 & 28278 & 30486 & 32601 & 36457 \\
\hline
\end{tabular}

Pada tabel 1. disajikan informasi berkaitan dengan pergerakan pesawat dari tahun 2011-2015 pada setiap bulan. Data pergerakan pesawat tersebut dibedakan antara data kedatangan (Arr) dan data keberangkatan (Dep). Contoh pada lingkaran 791 menunjukkan jumlah kedatangan pesawat pada 
bulan Februari 2011, sedangkan 789 menunjukkan jumlah kedatangan pesawat pada bulan Februari 2011.

Secara akumulasi per tahun, data pada Tabel 4.1 disajikan dalam gambar 2.

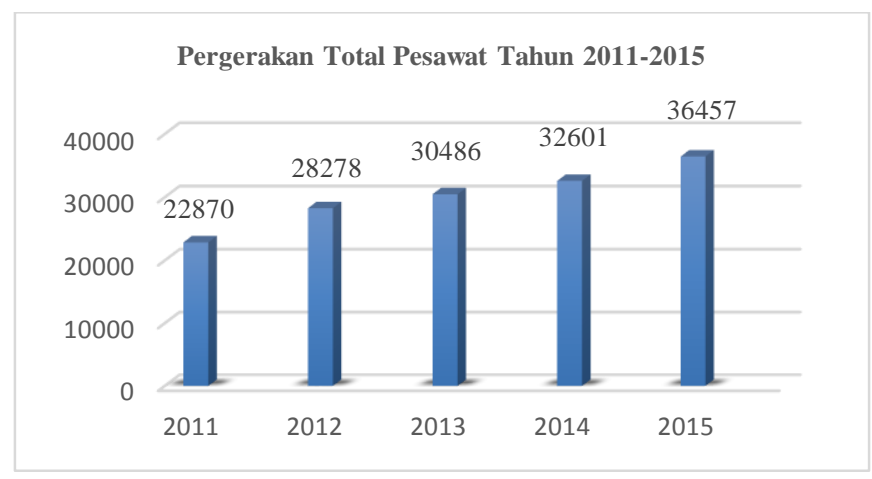

Gambar 2. Grafik Pergerakan Total Pesawat Tahun 2011-2015

\section{1) Analisis Peramalan Pertumbuhan Pergerakan Pesawat}

Pada perencanaan suatu bandar udara diperlukan perhitungan untuk memprediksi pertumbuhan pergerakan pesawat dan penumpang suatu bandar udara. Peramalan ini dilakukan sebagai kebutuhan suatu bandar udara serta untuk mengevaluasi 20 tahun kedepan dalam perhitungan peramalan.

2) Peramalan Pertumbuhan Pergerakan Pesawat dengan Metode Regresi Linier Berganda

Metode regresi linier berganda adalah perhitungan regresi yang berdasarkan ekonomi dimana rumusan tersebut berasal dari antar variabel yang terdiri dari beberapa skenario. Analisis perhitungan peramalan ini berdasarkan data pesawat ditahun 2011-2015 (sebagai data historis) dengan prediksi pertumbuhan variabel X (variable bebas), maka didapatkan pertumbuhan pesawat di tahun rencana dari setiap skenarionya.

Adapun skenario prakiraan peramalan yang digunakan meliputi 7 persamaan regresi linier dengan skenario variabel bebas masing-masing sebagai berikut :
a. Skenario $1: \mathrm{y}=\mathrm{a}+\mathrm{bX} 1$
b. Skenario 2: $y=a+b X 2$
c. Skenario $3: \mathrm{y}=\mathrm{a}+\mathrm{bX} 3$
d. Skenario $4: \mathrm{y}=\mathrm{a}+\mathrm{bX} 1+\mathrm{cX} 2$
e. Skenario $5: \mathrm{y}=\mathrm{a}+\mathrm{bX} 1+\mathrm{cX} 3$
f. Skenario $6: y=a+b X 2+c X 3$
g. Skenario $7: y=a+b X 1+c X 2+d X 3$

Dari 7 skenario kemudian dipilih 1 skenario yang nilai peramalannya paling mendekati dengan nilai data tahun 2015 .

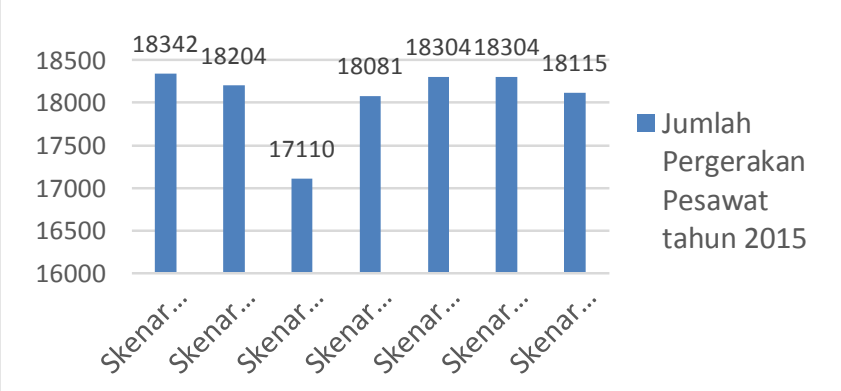

Gambar 3. Grafik Peramlan Jumlah Pergerakan Pesawat Tahun 2015

Berdasarkan gambar 3 di ketahui bahwa jumlah pergerakan pesawat yang mendekati data historis tahun 2015 adalah skenario 5 dan skenario 6, dengan data historis tahun 2015 adalah 18258. Dikarenakan hasil skenario 5 dan skenario 6 sama maka dicari Rsquare yang terbesar. Diantara kedua skenario tersebut Rsquare yang terbesar adalah skenario 6 yaitu 0,9740 .

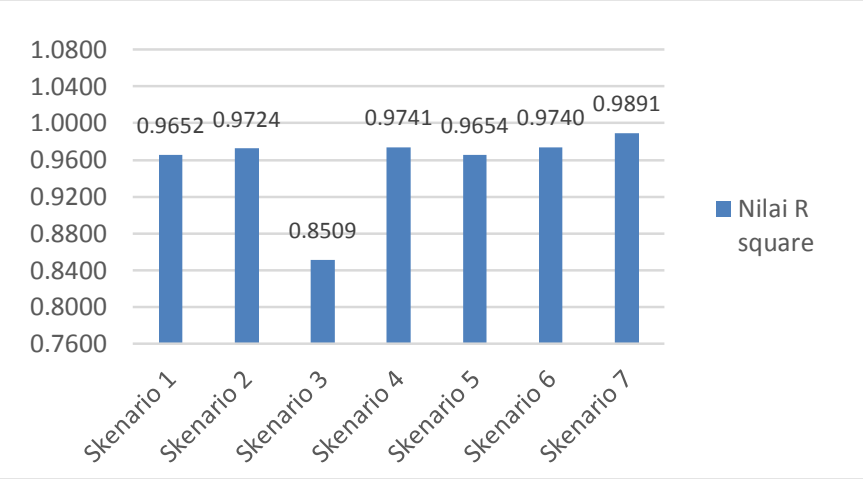

Gambar 3. Grafik Peramlan nilai R square

Berdasarkan gambar 4.8 diketahui bahwa nilai R square yang terbesar antara skenario 5 dan 6 adalah skenario 6 sebesar 0,9740 .

Untuk hasil perhitungan perhitungan peramalan pergerakan pesawat tiap tahun dapat dilihat pada tabel 2.

Tabel 2.

Hasil Peramalan Menggunakan Metode Regresi Linier Berganda

\begin{tabular}{cccc}
\hline \hline Tahun & Jumlah Pesawat & Tahun & Jumlah Pesawat \\
\hline 2016 & 19837 & 2026 & 35828 \\
2017 & 21417 & 2027 & 37426 \\
2018 & 23062 & 2028 & 39026 \\
2019 & 24647 & 2029 & 40624 \\
2020 & 26226 & 2030 & 42221 \\
2021 & 27840 & 2031 & 43820 \\
2022 & 29442 & 2032 & 45418 \\
2023 & 31029 & 2033 & 47016 \\
2024 & 32631 & 2034 & 48614 \\
2025 & 34233 & 2035 & 50213 \\
\hline \hline
\end{tabular}

Jadi jumlah pesawat di tahun rencana (2035) dalam perhitungan menggunakan peramalan ekonometrik pergerakan keberangkatan pesawat adalah 50.213 pergerakan.

3) Peramalan Pertumbuhan Pergerakan Pesawat dengan Metode Regresi Linier

Analisis perhitungan peramalan ini berdasarkan data pesawat di tahun 2011-2015 (sebagai data historis). Dalam permodelan regresi linier yang digunakan adalah data 2011-2014. Data 2015 digunakan untuk validasi model yang dihasilkan $\mathrm{Y}=1578,6(\mathrm{x})$ +10329 . Proses perhitungan ini dapat dilihat pada gambar 2 .

\section{Data Pergerakan Keberangkatan Pesawat}

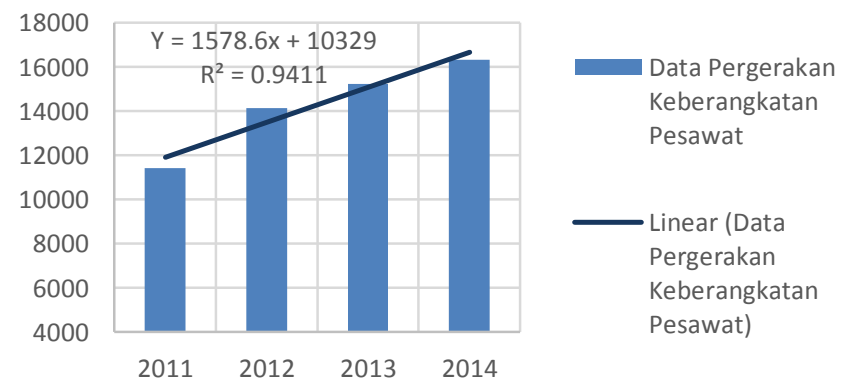

Gambar 4. Regresi Linier Data Pertumbuhan Pergerakan Keberangkatan Pesawat

Dari gambar 4 didapatkan persamaan regresi $Y=1578,6(x)+10329$ dan koefisien determinasinya $\left(R^{2}\right)$ sebesar 0.9411. Berdasarkan pola trend yang dihasilkan dari gambar 4, diperoleh pergerakan keberangkatan pesawat tahun 2015 adalah 18222. Dari hasil tersebut diketahui selisih pesawat yaitu $18258-18222=-36$

Selisih (-36) pergerakan pesawat tersebut menjadikan pola trend yang diperoleh dari metode regresi linier tidak digunakan. 


\section{B. Penentuan Peak Month, Peak Day, dan Peak Hour}

Berdasarkan data eksisting jumlah rata-rata pergerakan harian pesawat dalam 1 tahun dan jumlah pergerakan pesawat pada bulan puncak dalam 1 tahun, dapat diketahui peak month ratio. Peak month ratio ini diperlukan untuk mendapatkan nilai jumlah pergerakan pesawat pada bulan puncak dalam tahun yang dikehendaki. Sehingga pola puncak jumlah pergerakan pesawat adalah sama dengan pada tahun eksisting.

Tabel 4

Hasil Rekapitulasi Peak Month Ratio, Peak Day Ratio, Peak Hour Ratio

\begin{tabular}{clc}
\hline \hline No & \multicolumn{1}{c}{ Jenis Ratio } & Ratio \\
\hline 1 & Peak Month Ratio & 0.0945 \\
2 & Peak Day Ratio & 0.0372 \\
3 & Peak Hour Ratio & 0.3158 \\
\hline \hline
\end{tabular}

Untuk mengetahui jumlah pergerakan pesawat pada bulan puncak Tahun 2035, didapat dengan cara jumlah pesawat dalam setahun dikali dengan peak month ratio. Contoh perhitungan tahun 2035 dapat dilakukan dengan langkah sebagai berikut :

$$
\begin{aligned}
\mathrm{N} \text { month } & =\mathrm{N} \text { year } \times \mathrm{R} \text { month } \\
& =50213 \times 0,0945 \\
& =4745 \text { pesawat }
\end{aligned}
$$

Tabel 5 .

Hasil PeramalanJumlah Pergerakan Pesawat Pada Bulan Puncak

\begin{tabular}{ccc}
\hline \hline Tahun ke- & Tahun & $\begin{array}{c}\text { Jumlah Pergerakan Pesawat Pada } \\
\text { Bulan Puncak }\end{array}$ \\
\hline 6 & 2016 & 1875 \\
7 & 2017 & 2024 \\
8 & 2018 & 2180 \\
9 & 2019 & 2329 \\
10 & 2020 & 2479 \\
11 & 2021 & 2631 \\
12 & 2022 & 2782 \\
13 & 2023 & 2932 \\
14 & 2024 & 3084 \\
15 & 2025 & 3235 \\
16 & 2026 & 3386 \\
17 & 2027 & 3537 \\
18 & 2028 & 3688 \\
19 & 2029 & 3839 \\
20 & 2030 & 3990 \\
21 & 2031 & 4141 \\
22 & 2032 & 4292 \\
23 & 2033 & 4443 \\
24 & 2034 & 4594 \\
25 & 2035 & 4745 \\
\hline \hline
\end{tabular}

Untuk mengetahui jumlah pergerakan harian pesawat pada bulan puncak Tahun 2035, didapat dengan cara jumlah pergerakan pesawat pada bulan puncak dikali dengan peak day ratio. Contoh perhitungan tahun 2035 dapat dilakukan dengan langkah sebagai berikut :

$\mathrm{N}$ day = $\mathrm{N}$ month $\times \mathrm{R}$ day

$$
\begin{aligned}
& =4745 \times 0,0372 \\
& =176 \text { pesawat }
\end{aligned}
$$

Tabel 6

Hasil Peramalan Jumlah Pergerakan Pesawat pada Hari Tersibuk

\begin{tabular}{ccc} 
Tahun ke- & Tahun & $\begin{array}{c}\text { Jumlah Pergerakan Pesawat Pada } \\
\text { Hari Tersibuk }\end{array}$ \\
\hline 6 & 2016 & 70 \\
7 & 2017 & 75 \\
8 & 2018 & 81 \\
\hline \hline
\end{tabular}

\begin{tabular}{lll}
\hline \hline 9 & 2019 & 87 \\
10 & 2020 & 92 \\
11 & 2021 & 98 \\
12 & 2022 & 103 \\
13 & 2023 & 109 \\
14 & 2024 & 115 \\
15 & 2025 & 120 \\
16 & 2026 & 126 \\
17 & 2027 & 132 \\
18 & 2028 & 137 \\
19 & 2029 & 143 \\
20 & 2030 & 148 \\
21 & 2031 & 154 \\
22 & 2032 & 160 \\
23 & 2033 & 165 \\
24 & 2034 & 171 \\
25 & 2035 & 176 \\
\hline \hline
\end{tabular}

Untuk mengetahui jumlah pergerakan pesawat kondisi peak hour pada hari tersibuk bulan puncak Tahun 2035, didapat dengan cara jumlah pergerakan pesawat harian pada bulan puncak dikali dengan peak hour ratio. Contoh perhitungan dapat dilakukan dengan langkah sebagai berikut:

$$
\begin{aligned}
\mathrm{N} \text { hour } & =\mathrm{N} \text { day } \times \mathrm{R} \text { hour } \\
& =176 \times 0.3158 \\
& =56 \text { pesawat }
\end{aligned}
$$

Tabel 7.

Hasil Peramalan Jumlah Pergerakan Pesawat di Apron pada Jam Puncak

\begin{tabular}{ccc}
\hline $\begin{array}{c}\text { Tahun } \\
\text { ke- }\end{array}$ & Tahun & $\begin{array}{c}\text { Jumlah Pergerakan Pesawat Pada } \\
\text { Jam Puncak }\end{array}$ \\
\hline 6 & 2016 & 22 \\
7 & 2017 & 24 \\
8 & 2018 & 26 \\
9 & 2019 & 27 \\
10 & 2020 & 29 \\
11 & 2021 & 31 \\
12 & 2022 & 33 \\
13 & 2023 & 34 \\
14 & 2024 & 36 \\
15 & 2025 & 38 \\
16 & 2026 & 40 \\
17 & 2027 & 42 \\
18 & 2028 & 43 \\
19 & 2029 & 45 \\
20 & 2030 & 47 \\
21 & 2031 & 49 \\
22 & 2032 & 50 \\
23 & 2033 & 52 \\
24 & 2034 & 54 \\
25 & 2035 & 56 \\
\hline \hline
\end{tabular}

Jadi, dari perhitungan diatas didapat jumlah pergerakan pesawat pada saat jam puncak tahun rencana (2035) adalah 56 pergerakan. Selanjutnya jumlah pergerakan pesawat saat jam puncak ini untuk menghitung jumlah kebutuhan parking stand.

\section{Perhitungan Jumlah Gerbang Landas Parkir [3]}

Penentuan jumlah gerbang landas parkir yang dibutuhkan menggunakan rumusan sebagai berikut :

Dimana:

$$
G=\frac{V \cdot T}{U}
$$

G : Jumlah Gate

$\mathrm{V}$ : Volume desain untuk kedatangan atau 
keberangkatan (gerakan/jam)

$\mathrm{T}$ : Waktu pemakaian / parkir di gate (jam)

- Untuk kelas $A=60$ menit

- Untuk kelas $B=40$ menit

- Untuk kelas $\mathrm{C}=30$ menit

$\mathrm{U}$ : Faktor pemakaian gate $0,6-0,8$

Tabel 8.

Jumlah Pesawat Terbang Berdasarkan Kelas

\begin{tabular}{cccc}
\hline \hline Tahun & \multicolumn{2}{c}{ Jumlah Pesawat Terbang } & Total \\
\hline 2016 & Kelas C & Kelas D & \\
2017 & 17 & 5 & 22 \\
2018 & 18 & 6 & 24 \\
2019 & 20 & 6 & 26 \\
2020 & 21 & 6 & 27 \\
2021 & 22 & 7 & 29 \\
2022 & 23 & 8 & 31 \\
2023 & 25 & 8 & 33 \\
2024 & 25 & 9 & 34 \\
2025 & 27 & 9 & 36 \\
2026 & 28 & 10 & 38 \\
2027 & 30 & 10 & 40 \\
2028 & 32 & 10 & 42 \\
2029 & 32 & 11 & 43 \\
2030 & 34 & 11 & 45 \\
2031 & 35 & 12 & 47 \\
2032 & 37 & 12 & 49 \\
2033 & 37 & 13 & 50 \\
2034 & 39 & 13 & 52 \\
2035 & 40 & 14 & 56 \\
\hline \hline
\end{tabular}

Setelah mengetahui jumlah pergerakan pesawat berdasarkan kelasnya maka dilanjutkan menghitung jumlah gerbang landas parkir.

Tabel 9.

Jumlah gerbang landas parker

\begin{tabular}{|c|c|c|c|}
\hline \multicolumn{4}{|c|}{ Jumlah gerbang landas parker } \\
\hline \multirow{2}{*}{ Tahun } & \multicolumn{2}{|c|}{ Jumlah Pesawat Terbang } & \multirow{2}{*}{ Tota } \\
\hline & Kelas C & Kelas D & \\
\hline 2016 & 14 & 6 & 20 \\
\hline 2017 & 15 & 7 & 22 \\
\hline 2018 & 17 & 7 & 23 \\
\hline 2019 & 18 & 7 & 24 \\
\hline 2020 & 18 & 8 & 26 \\
\hline 2021 & 19 & 9 & 28 \\
\hline 2022 & 21 & 9 & 30 \\
\hline 2023 & 21 & 10 & 31 \\
\hline 2024 & 23 & 10 & 33 \\
\hline 2025 & 23 & 11 & 34 \\
\hline 2026 & 25 & 11 & 36 \\
\hline 2027 & 27 & 11 & 38 \\
\hline 2028 & 27 & 12 & 39 \\
\hline 2029 & 28 & 12 & 41 \\
\hline 2030 & 29 & 13 & 43 \\
\hline 2031 & 31 & 13 & 44 \\
\hline 2032 & 31 & 14 & 45 \\
\hline 2033 & 33 & 14 & 47 \\
\hline \multicolumn{4}{|c|}{$\begin{array}{c}\text { Tabel } 9 . \\
\text { Lanjutan }\end{array}$} \\
\hline \multirow[t]{2}{*}{ Tahun } & \multicolumn{2}{|c|}{ Jumlah Pesawat Terbang } & Total \\
\hline & Kelas C & Kelas D & \\
\hline 2034 & 33 & 16 & 49 \\
\hline 2035 & 35 & 16 & 51 \\
\hline
\end{tabular}

Dari tabel 9 didapatkan jumlah total gerbang landas parkir untuk tahun rencana (2035) sebesar 51.

\section{Ukuran Gerbang Landas Parkir}

Penentuan dimensi gerbang landas parkir yang dibutuhkan menggunakan rumusan sebagai berikut :

- $\quad$ Panjang apron $=\mathrm{G} \times 2 \mathrm{R}+\mathrm{G} \times \mathrm{C}$

- $\quad$ Lebar apron $=\mathrm{L}+\mathrm{C}+\mathrm{W}$; untuk 1 taxi lane Dimana :

$\mathrm{G}=$ Jumlah gate

$\mathrm{R}=$ Radius putar pesawat $(\mathrm{ft})$

$\mathrm{C}=$ Jarak pesawat ke pesawat dan pesawat ke gedung terminal $(25-35 \mathrm{ft})$

$\mathrm{L}=$ Panjang pesawat $(\mathrm{ft})$

$\mathrm{W}=$ lebar taxi lane $(160 \mathrm{ft}$ untuk pesawat kecil dan $290 \mathrm{ft}$ untuk pesawat berbadan lebar)

Tabel 10.

Hasil Perhitungan Dimensi landas parkir kelas C

\begin{tabular}{cccc}
\hline \hline Tahun & $\begin{array}{c}\text { Panjang Apron } \\
(\mathrm{m})\end{array}$ & $\begin{array}{c}\text { Lebar Apron } \\
(\mathrm{m})\end{array}$ & Luas $(\mathrm{m} 2)$ \\
\hline 2016 & 838.60 & 98.37 & 82491 \\
2017 & 898.50 & 98.37 & 88384 \\
2018 & 1018.30 & 98.37 & 100168 \\
2019 & 1078.20 & 98.37 & 106060 \\
2020 & 1078.20 & 98.37 & 106060 \\
2021 & 1138.10 & 98.37 & 111953 \\
2022 & 1257.90 & 98.37 & 123737 \\
2023 & 1257.90 & 98.37 & 123737 \\
2024 & 1377.70 & 98.37 & 135522 \\
2025 & 1377.70 & 98.37 & 135522 \\
2026 & 1497.50 & 98.37 & 147306 \\
2027 & 1617.30 & 98.37 & 159091 \\
2028 & 1617.30 & 98.37 & 159091 \\
2029 & 1677.20 & 98.37 & 164983 \\
2030 & 1737.10 & 98.37 & 170875 \\
2031 & 1856.90 & 98.37 & 182660 \\
2032 & 1856.90 & 98.37 & 182660 \\
2033 & 1976.70 & 98.37 & 194444 \\
2034 & 1976.70 & 98.37 & 194444 \\
2035 & 2096.50 & 98.37 & 206229 \\
\hline \hline
\end{tabular}

Jadi untuk dimensi landas parkir kelas $\mathrm{C}$ untuk tahun rencana (2035) membutuhkan panjang 2096,50 m dan lebar 98,37m dengan luas $206229 \mathrm{~m} 2$.

Tabel 11.

Hasil Perhitungan Dimensi landas parkir kelas D

\begin{tabular}{|c|c|c|c|}
\hline Tahun & $\begin{array}{l}\text { Panjang Apron } \\
\text { (m) }\end{array}$ & $\begin{array}{l}\text { Lebar Apron } \\
(\mathrm{m})\end{array}$ & Luas (m2) \\
\hline 2016 & 580.20 & 104.78 & 60792 \\
\hline 2017 & 676.90 & 104.78 & 70924 \\
\hline 2018 & 676.90 & 104.78 & 70924 \\
\hline 2019 & 676.90 & 104.78 & 70924 \\
\hline 2020 & 773.60 & 104.78 & 81056 \\
\hline 2021 & 870.30 & 104.78 & 91188 \\
\hline 2022 & 870.30 & 104.78 & 91188 \\
\hline 2023 & 967.00 & 104.78 & 101320 \\
\hline 2024 & 967.00 & 104.78 & 101320 \\
\hline 2025 & 1063.70 & 104.78 & 111452 \\
\hline \multicolumn{4}{|c|}{$\begin{array}{l}\text { Tabel } 11 . \\
\text { Lanjutan }\end{array}$} \\
\hline Tahun & $\begin{array}{l}\text { Panjang Apron } \\
\text { (m) }\end{array}$ & $\begin{array}{l}\text { Lebar Apron } \\
\text { (m) }\end{array}$ & Luas (m2) \\
\hline 2026 & 1063.70 & 104.78 & 111452 \\
\hline 2027 & 1063.70 & 104.78 & 111452 \\
\hline 2028 & 1160.40 & 104.78 & 121584 \\
\hline 2029 & 1160.40 & 104.78 & 121584 \\
\hline 2030 & 1257.10 & 104.78 & 131716 \\
\hline
\end{tabular}




\begin{tabular}{llll}
\hline \hline 2031 & 1257.10 & 104.78 & 131716 \\
2032 & 1353.80 & 104.78 & 141848 \\
2033 & 1353.80 & 104.78 & 141848 \\
2034 & 1547.20 & 104.78 & 162113 \\
2035 & 1547.20 & 104.78 & 162113 \\
\hline \hline
\end{tabular}

Jadi untuk dimensi landas parkir kelas D untuk tahun rencana (2035) membutuhkan panjang 1547,20 m dan lebar 104,78 m dengan luas $162113 \mathrm{~m} 2$.

Tabel 12.

Hasil Perhitungan Total Dimensi landas parkir kelas C dan D

\begin{tabular}{lccc}
\hline \hline Tahun & Panjang Apron $(\mathrm{m})$ & $\begin{array}{c}\text { Lebar Apron } \\
(\mathrm{m})\end{array}$ & Luas $(\mathrm{m} 2)$ \\
\hline 2016 & 1418.80 & 203.15 & 143284 \\
2017 & 1575.40 & 203.15 & 159308 \\
2018 & 1635.30 & 203.15 & 165200 \\
2019 & 1695.20 & 203.15 & 171092 \\
2020 & 1851.80 & 203.15 & 187117 \\
2021 & 2008.40 & 203.15 & 203141 \\
2022 & 2128.20 & 203.15 & 214925 \\
2023 & 2284.80 & 203.15 & 230950 \\
2024 & 2344.70 & 203.15 & 236842 \\
2025 & 2441.40 & 203.15 & 246974 \\
2026 & 2561.20 & 203.15 & 258758 \\
2027 & 2681.00 & 203.15 & 270543 \\
2028 & 2777.70 & 203.15 & 280675 \\
2029 & 2897.50 & 203.15 & 292459 \\
2030 & 3054.10 & 203.15 & 308484 \\
2031 & 3114.00 & 203.15 & 314376 \\
2032 & 3270.60 & 203.15 & 330400 \\
2033 & 3330.50 & 203.15 & 336292 \\
2034 & 3523.90 & 203.15 & 356557 \\
2035 & 3643.70 & 203.15 & 368341 \\
\hline \hline
\end{tabular}

Dari hasil diatas didapatkan total dimensi landas parkir rencana (2035) Bandar Udara Internasional Ahmad Yani Semarang adalah dengan panjang 3643,70 $\mathrm{m}$ dan lebar 203,15 m dengan luas $368341 \mathrm{~m} 2$.

\section{E. Perencanaan Tebal Perkerasan Landas Parkir}

Dalam perencanaan perkerasan landas parkir di Bandar Udara Inernasional Ahmad Yani Semarang menggunakan perkerasan kaku (rigid pavement).

Tabel 13.

Tebal Lapis Perkerasan Kaku

\begin{tabular}{ccc}
\hline \hline Layer & $\begin{array}{c}\text { Ketebalan } \\
(\mathrm{mm})\end{array}$ & $\begin{array}{c}\text { Pembulatan Tebal } \\
(\mathrm{mm})\end{array}$ \\
\hline PCC Surface & 512,4 & 515 \\
P-304 (Cement Treated Base) & 152,4 & 155 \\
Total & $\mathbf{6 6 4 , 8}$ & $\mathbf{6 7 0}$ \\
\hline \hline
\end{tabular}

\section{F. Perencanaan Penulangan Perkerasan Landas Parkir [4]}

Dalam perencanaan penulangan landas parkir di Bandar Udara Inernasional Ahmad Yani Semarang menggunakan wiremesh dengan D14-100. Selain itu sebagai penyambung antar slab beton dibutuhkan Dowel dengan diameter $50 \mathrm{~mm}$, panjang $610 \mathrm{~mm}$, dan jarak $460 \mathrm{~mm}$. Tulangan wiremesh dalam perhitungan ini didapatkan D14-100.

\section{KESIMPULAN DAN SARAN}

\section{A. Kesimpulan}

Berdasarkan hasil analisis pada bab sebelumnya, dapat disimpulkan bahwa hasil penelitian ini adalah sebagai berikut :

1. Dari data yang didapatkan diketahui bahwa selama 5 tahun terakhir pertumbuhan pergerakan pesawat mengalami kenaikan. Di tahun 2011 total pergerakan pesawat sebesar 22870 pergerakan sedangkan tahun 2015 sebesar 36457 pergerakan.

2. Pertumbuhan pergerakan pesawat diramalkan dengan metode Ekonometrik dengan data penunjang variabel bebas yang terdiri dari beberapa skenario. Sehingga diperkirakan jumlah pergerakan keberangkatan pesawat di tahun 2015 sebesar 18258 pergerakan menjadi 50448 pergerakan di tahun 2035.

3. Berdasarkan hasil analisis perhitungan jam puncak didapat jumlah pergerakan pesawat pada jam puncak tahun 2035 sebesar 56 pergerakan. Sehingga kebutuhan parking stand pada tahun 2035 sebanyak 51.

4. Berdasarkan hasil peramalan parking stand pada tahun 2016 s.d 2035 diketahui bahwa dimensi landas parkir tahun 2035 untuk kelas $\mathrm{C}$ adalah dengan panjang 2096,50 $\mathrm{m}$ dan lebar $98,37 \mathrm{~m}$. Sedangkan untuk kelas D adalah panjang 1547,20 m dan lebar 104,78 m.

5. Berdasakan hasil perhitungan tebal landas parkir dengan metode FAARFIELD diketahui bahwa tebal pada PCC Surface adalah 515 mm, sedangkan untuk P-304 (Cement Treated Base) adalah $155 \mathrm{~mm}$.

6. Berdasarkan hasil perhitungan penulangan landas parkir dengan metode FAA didapatkan wiremesh dengan D14100 dan Dowel dengan diameter $50 \mathrm{~mm}$, panjang 610, dan jarak $460 \mathrm{~mm}$.

B. Saran

Adapun saran dalam evaluasi kebutuhan apron rencana Bandar Udara Internasional Ahmad Yani Semarang sebagai berikut :

1. Untuk kebutuhan parking stand Bandar Udara Internasional Ahmad Yani Semarang pada tahun 2035 tidak bisa menampung pesawat karena landasan parkir yang ada tidak mencukupi pergerakan pesawat yang ada. oleh karena itu apron di bandara ini harus di perluas lagi.

2. Untuk tahun rencana (2035) dengan adanya penambahan jumlah parking stand sejumlah 51, jadi Bandar Udara Internasional Ahmad Yani Semarang perlu menambah jumlah taxiway.

\section{DAFTAR PUSTAKA}

[1] http://www.angkasapura1.co.id/detail/berita/bandara-ahmad-yani-pprampung-proyek-perluasan-dimulai-bulan-ini)

[2] PT. (persero) Angkasa Pura I. (2016). Data Histori Pergerakan Pesawat di Bandara Ahmad Yani Semarang.

[3] Horonjeff R., \& Mckelvey. F. X. (2010). Planning \& Design of Airports (Fifth Edit). New York: Mc Graw Hill, Inc.

[4] FAA. (2009). Airport Pavement Design and Evaluation. 